\title{
Dehydroepiandrosterone-Regulated Testosterone Biosynthesis via Activation of the ERK1/2 Signaling Pathway in Primary Rat Leydig Cells
}

\author{
Lin Liu Jian Kang Xiao Ding Di Chen Yingqiao Zhou Haitian Ma
}

Key Laboratory of Animal Physiology and Biochemistry, College of Veterinary Medicine, Nanjing Agricultural University, Nanjing, China

\section{Key Words}

Dehydroepiandrosterone - Testosterone biosynthesis - ERK signaling pathway - Primary Leydig cell

\begin{abstract}
Background: Dehydroepiandrosterone decreases with age and this reduction has been shown to be associated with physical health in human. Some studies have suggested that the effects of DHEA are exerted after it is biotransformed into more biologically-active hormones in peripheral target cells. This study investigated the effects of DHEA on the testosterone biosynthesis and possible signaling pathway mechanism underlying these DHEA effects were also explored in primary rat Leydig cells. Methods: Primary Leydig cells were treated with DHEA and then detected testosterone content by RIA and steroidogenic enzymes, ERK1/2 signal pathway factors protein expression level by Western blot. Results: Incubation of primary Leydig cells with DHEA significantly increased testosterone content and $3 \beta-H S D$ and $17 \beta$-HSD protein expression levels, while aromatase protein expression levels were decreased. Compared with the control group, $\mathrm{p}$-ERK1/2 and $\mathrm{p}$-CREB protein levels were significantly increased in DHEA-treated groups. Testosterone content was significantly decreased in the DHEA-treated group pre-incubated with U0126 ( $p$-ERK1/2 inhibitor). Additionally, the rise in $\mathrm{p}$-ERK1/2,3 $\beta$-HSD and 17 $\beta$-HSD protein levels induced by DHEA was reversed when cells were pre-incubated with U0126. Interestingly, no significant difference was found in aromatase protein expression level in cells pretreated with U0126. Conclusion: These findings demonstrate that (a) exogenous DHEA might preferentially convert to testosterone rather than estradiol due to the up-regulation of $3 \beta-H S D$ and $17 \beta-H S D$ protein levels and the downregulation of aromatase protein level in primary Leydig cells, and (b) the action of DHEA is at least partly associated with the elevation of $p$-ERK1/2 and $p$-CREB protein levels.
\end{abstract}

Copyright $\odot 2015$ S. Karger AG, Basel 


\section{Introduction}

Dehydroepiandrosterone (DHEA) is the major steroid hormone produced by the adrenal zona reticularis. One of the main characteristics of DHEA is its age-dependent pattern of secretion; its production begins during fetal life, reaches the highest serum levels between the age of 20 and 30 years, and then steadily declines at a rate of $2 \%$ to $5 \%$ per year, resulting in a decline of up to $80 \%$ in old age $[1,2]$. Significant clinical interest in the decrease in DHEA with age exists because this reduction has been shown to be associated with physical health [3-5]. Outside of the regular pharmaceutical networks in the United States, DHEA is widely commercially available as a non-prescription dietary supplement [6]. Surprisingly, despite extensive studies linking DHEA conversion to more active androgens and estrogens in either peripheral tissues or target cells, the mechanism of action of DHEA remains elusive. Most of DHEA in humans is synthesized by the adrenal glands, while in rodents active DHEA is locally produced in different tissues [7]. Moreover, the circulating DHEA levels in mice and rats are often unmeasurable, which indicated that in rat endogenous DHEA production is negligible [8]. Although endogenous DHEA secretion could be negligible, there many reported that DHEA could convert to activate steroids hormones in rats [9-11].

The exact mechanisms of DHEA action are unknown, some effects may be due its conversion to androgens and estrogens [12]. By acting as the available precursor that is converted to testosterone and estrogens in various peripheral tissues, DHEA plays a critical physiological role in maintaining steroidogenesis. As a steroid hormone precursor, DHEA can be rapidly converted into androstenedione by $3 \beta$-hydroxysteroid dehydrogenase (3ß-HSD) in peripheral target tissues, and then undergo further conversion to testosterone and estradiol by $17 \beta$-hydroxysteroid dehydrogenase (17 $\beta$-HSD) and aromatase, respectively [13-16]. In vitro studies using osteoblasts (OBs) demonstrated that DHEA can be metabolized to testosterone by $17 \beta$ - and $3 \beta$-HSD and further metabolized to DHT by the $5 \mathrm{a}$-reducatase [17]. Our previous study demonstrated that serum concentrations of testosterone, estradiol and aldosterone in rats were markedly increased following treatment with DHEA [18]. Other studies also showed that the contents of androstenedione and testosterone were significantly increased in aged adults following treatment with DHEA $[15,16]$. Although DHEA in primates is secreted primarily by the adrenal cortex, whereas little or no DHEA is produced by the adrenal cortex in mice and rats [8], exogenous DHEA can be transformed into active androgens or estrogens in peripheral tissues, which contain various steroidogenic enzymes [15]. In males, $\sim 95 \%$ of androgen biosynthesis and secretion occurs in Leydig cells, which are situated in the testicular interstitium. Previous studies have suggested that functional changes in Leydig cells, rather than cell loss, account for the observed reduction in serum testosterone levels [3]. Recent studies from our laboratory also demonstrated that exogenous DHEA inhibited TM-3 (a Leydig cell line) cell growth by decreasing the activity of G6PD and the expression of cyclin mRNA; it also improved TM-3 cell viability by increasing mitochondrial membrane permeability along with the activity of succinate dehydrogenase [19]. The Leydig cells of rats are known to possess 3 $\beta$-HSD, 17 $\beta$-HSD and aromatase, which catalyze the formation of testosterone and estradiol [20]. However, to our knowledge, little information is available regarding the effects of DHEA on the expression of steroidogenic enzyme protein expression in primary Leydig cells.

In adult steroidogenic tissues, the levels of most cell- and tissue-specific steroidogenic enzymes depends mainly on trophic hormonal stimulation, which is mediated by a complex network of signal transduction systems [21]. Extracellular signal-regulated kinases (ERKs) belonging to the family of signaling mitogen-activated protein kinases (MAPKs) were first implicated in the regulation of enzyme proliferation and differentiation [22]. However, several studies suggest that the signaling pathway of ERKs can play a critical role in steroidogenesis [23, 24]. DHEA is known to be a strong activator of the MEK/ERK pathway. Charalampopoulos et al. [25] found that DHEA effects in PC12 cells are membrane-mediated and involve PKA and MAPK pathways but not a nuclear receptor. Chang et al. $[9,26]$ reported that DHEA-inhibited corticosterone is released from rat adrenal zona fasciculata-

\section{KARGER}


Liu et al.: DHEA Modulated Testosterone Biosynthesis

reticularis cells in a manner partly related to the post-cAMP pathway, diminishing the expression of steroidogenic enzymes. Additional studies suggested that DHEA affects the phosphorylation/activation of ERKs by enhancing phosphorylation of the steroidogenic factor-1 (SF-1) and regulating the protein expression of steroidogenic enzymes. Moriguchi et al. [27] reported that DHEA restored reduced ERK phosphorylation concomitant with increased CREB phosphorylation in the hippocampal ca1 region of olfactory bulbectomized mouse. Nevertheless, the molecular mechanisms underlying these DHEA effects in Leydig cells remain unclear.

To better understand the mechanism of DHEA action, a study was carried out to investigate (1) whether DHEA activates the ERK1/2 signaling system in cultured rat primary Leydig cells, which regulate the protein expression of steroidogenic enzymes and, subsequently (2) whether DHEA improves testosterone biosynthesis through activation of the ERK1/2 pathway. This information is necessary to fully understand the cellular and molecular mechanisms by which DHEA exerts its biological effects in vivo.

\section{Material and Methods}

\section{Animals and materials}

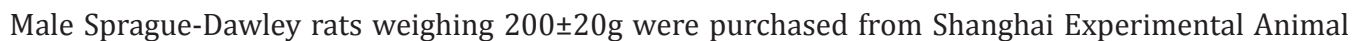
Center of the Chinese Academy of Sciences (China). Animals were housed one per cage under conditions of constant temperature $\left(25^{\circ} \mathrm{C}\right)$, constant humidity $(50 \%)$ and a 12:12-h light/dark cycle. Animals were maintained on standard rodent chow; food and water were available ad libitum. All animal handling procedures were performed in accordance with guidelines established by the People's Republic of China, and all procedures were pre-approved by the Institutional Animal Care and Use Committee of Nanjing Agricultural University.

DHEA, dimethyl sulfoxide (DMSO), penicillin, streptomycin, trypsin and percoll were purchased from Sigma (St Louis, MO, USA); transferrin, L-glutamine and HEPES were obtained from Amresco Inc. (Solon, OH, USA); DMEM/F12 medium and fetal bovine serum (FBS) were purchased from Hyclone (Hyclone, USA); the TRIZOL Reagent Kit was purchased from Invitrogen (CA, USA); the M-MLV reverse transcriptase, RNase inhibitor and dNTP mixture were obtained from Promega (Madison, USA); Ex Taq DNA polymerase came

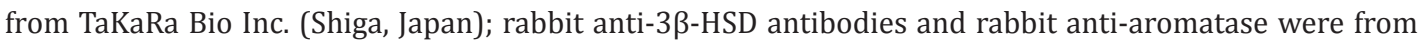
Abcam (Abcam, USA); rabbit anti-17 $\beta$-HSD antibody was purchased from Santa Cruz (Santa Cruz, CA); ERK1/2, p-ERK1/2, CERB, p-CREB, rabbit anti-GAPDH and the p-ERK1/2 inhibitor U1026 were purchased from Cell Signaling Technology (Cell Signaling Technology, USA); goat anti-rabbit IgG, horseradish peroxidase conjugate was purchased from Bioworld Technology Co. (Bioworld Technology Co., USA); protein assay kits were from the Biyuntian Bioengineering Institute (Nanjing, China); the testosterone radioimmunoassay (RIA) kits were purchased from the Beijing Beifang Biotechnology Institution (Beijing, China); and all other reagent details are indicated in the text.

Isolation, purification and identification of Leydig cells

Two rats were killed by decapitation, and their testes were decapsulated under aseptic conditions. The Leydig cells were isolated by enzymatic digestion and purified on a discontinuous Percoll gradient by the method described by Murugesan et al. [28]. In brief, testes were decapsulated using fine forceps without breaking the seminiferous tubules and digested in DMEM-F12 containing collagenase $(0.5 \%)$ at $37^{\circ} \mathrm{C}$ for $15 \mathrm{~min}$ in a thermostated shaking water bath. After this incubation, collagenase-free DMEM-F12 was added to each reaction, and the tubes were allowed stand for $3 \mathrm{~min}$ at room temperature without mixing. The supernatant was then aspirated using a Pasteur pipette and transferred to sterile centrifuge tubes. This procedure was repeated to remove additional Leydig cells. The supernatants were combined and centrifuged at $2500 \mathrm{x}$ g for $5 \mathrm{~min}$ at $4^{\circ} \mathrm{C}$. After discarding the supernatant, the obtained pellet was resuspended in $2 \mathrm{~mL}$ of DMEM-F12, which represented a crude testicular interstitial cell suspension. Discontinuous Percoll gradients were used to obtain purified Leydig cells from this crude preparation. Two milliliters of $75 \%$ Percoll gradient was added to a graduated centrifuge tube. Above this layer, 70\%, 58\%, 30\% and 5\% gradients of Percoll ( $2 \mathrm{~mL}$ of each) were gently laid one over the other, taking care to avoid mixing. Two milliliters of 
crude Leydig cell suspension was then applied on top of this discontinuous gradient and centrifuged at 3000 $\mathrm{x} g$ for $30 \mathrm{~min}$ at $4^{\circ} \mathrm{C}$. After centrifugation, most of the observed purified Leydig cells were in the 30\% Percoll gradients. These Leydig cells were transferred to centrifuge tubes containing DMEM-F12. After mixing, the tubes were centrifuged at $2500 \mathrm{x}$ g for $10 \mathrm{~min}$ at $4^{\circ} \mathrm{C}$, and the obtained supernatant was discarded. To remove excess Percoll, the cell pellets were washed three times with excess medium and finally suspended in $1 \mathrm{~mL}$ of DMEM-F12. The purities of the Leydig cells were assessed by histochemical localization of 3 $\beta$-HSD performed according to the method of Aldred and Cooke [29]. The viability of the purified Leydig cells was determined by trypan blue dye exclusion [29].

\section{Primary culture of Leydig cells}

Primary Leydig cells were plated in six-well plastic culture plates (Nunc Company, Roskilde, Denmark) at a density of $1 \times 10^{6}$ cells per well in $2 \mathrm{~mL}$ of DMEM-F12 medium. Supplements were added using $10 \%$ FBS, transferrin $(5 \mathrm{mg} / \mathrm{mL}), 2 \mathrm{mM}$ L-glutamine and $1.75 \mathrm{mM}$ HEPES. The culture medium also contained penicillin $(100 \mathrm{IU} / \mathrm{ml})$ and streptomycin $(100 \mathrm{mg} / \mathrm{mL})$. Primary Leydig cells were incubated at $37^{\circ} \mathrm{C}$ in an atmosphere of $95 \%$ air and $5 \% \mathrm{CO}_{2}$. Following $24 \mathrm{~h}$ of acclimatization to the culture environment, cells were incubated with serum-free medium for $1 \mathrm{~h}$ before the onset of experimental treatments.

\section{Cell viability assay}

Cells grown in 96-well plates $\left(1 \times 10^{4}\right.$ cells/well) were treated with $0,1,50$ or $100 \mu \mathrm{M}$ DHEA and cultured at $37^{\circ} \mathrm{C}$ for $24 \mathrm{~h}$. Then, $20 \mu \mathrm{L}$ of MTT $(5 \mathrm{mg} / \mathrm{mL})$ was added to each well. After $4 \mathrm{~h}$ of culture, the culture medium was removed and blue formazan crystals that had formed were dissolved in $50 \mu \mathrm{L}$ DMSO. The optical density of the formazan generated from MTT was measured at 490nm.

\section{Detection of testosterone content by radioimmunoassay (RIA)}

The concentration of testosterone in primary Leydig cells under basal or stimulated conditions was determined using an RIA kit. After culturing for $24 \mathrm{~h}$ in DMEM-F12 medium at $37^{\circ} \mathrm{C}$, cells were incubated with a dimethyl sulfoxide solution of DHEA $(1 \mu \mathrm{M}, 50 \mu \mathrm{M}$ or $100 \mu \mathrm{M})$ for $24 \mathrm{~h}(\mathrm{n}=6)$. A solution of $0.1 \%$ DMSO was used for the control group. Following incubation, cells were harvested, disrupted ultrasonically in ice, and centrifuged at $2500 \mathrm{xg}$ for $10 \mathrm{~min}$ at $4^{\circ} \mathrm{C}$. The supernatants were then collected and stored for subsequent analysis at $-20^{\circ} \mathrm{C}$. The testosterone concentrations in the supernatants were determined according to the manufacturer's instructions (intra-variation coefficients $<10 \%$, inter-variation coefficients $<15 \%$ ). Experiments were repeated three times and six.

\section{Assay of $3 \beta$-HSD and $17 \beta$-HSD expression by real-time quantitative PCR}

Following a $24 \mathrm{~h}$ equilibration to the culture environment, primary Leydig cells incubated in six-well plates was exposed to DHEA. Thereafter, the old culture medium was removed, and cells were resuspended in DMEM-F12 medium with a DMSO solution of DHEA $(1,50$ or $100 \mu \mathrm{M})$. Control cultures received an equal volume of DMSO, which did not exceed 0.25 vol- $\%$ in all experiments. Control and treated cells were left for $24 \mathrm{~h}$ in a humidified incubator at $37^{\circ} \mathrm{C}$ in an atmosphere of $95 \%$ air and $5 \% \mathrm{CO}_{2}$. Experiments were repeated three times, with six samples taken at each time point. Total RNA was immediately extracted from Leydig cells after incubation with DHEA by the TRIZOL reagent kit. The RNA concentration was then quantified by measuring absorbance at 260nm with a photometer (Eppendorf Biophotometer). Ratios of absorption $(260 / 280 \mathrm{~nm})$ for all preparations were between 1.8 and 2.0. Aliquots of RNA samples were subjected to electrophoresis through a $1.4 \%$ agarose/formaldehyde gel to verify their integrity. After adjustment of the RNA concentrations to $1 \mu \mathrm{g} / \mu \mathrm{L}$ by OD value measurement, the aliquots were stored at $-80^{\circ} \mathrm{C}$.

Two micrograms of total RNA were reverse-transcribed by incubation for $1 \mathrm{~h}$ at $37^{\circ} \mathrm{C}$ in a $25 \mu \mathrm{L}$ mixture consisting of $100 \mathrm{U}$ M-KGV reverse transcriptase, 8U RNase inhibitor, $0.5 \mu \mathrm{g}$ of Oligo(dT), 50mM Tris- $\mathrm{HCl}$ (pH 8.3), $3 \mathrm{mM} \mathrm{MgCl}_{2}, 75 \mathrm{mM} \mathrm{KCl}, 10 \mathrm{mM}$ DDT and $0.8 \mathrm{mM}$ dNTP. The reaction was stopped by heating to $95^{\circ} \mathrm{C}$ for $5 \mathrm{~min}$ and quickly cooling the mixture on ice. Real-time RT-PCR was performed with a SYBR Green PCR Master Mix Kit (Toyobo, Osaka, Japan) in an ABI7300 Detection System (Applied Biosystems) according to the manufacturer's instructions. The expression of $3 \beta-H S D$ and $17 \beta-H S D$ mRNA was determined by real-time quantitative RT-PCR. The relative amount of mRNA for each target gene was determined by calculating the ratio between each mRNA and $\beta$-actin mRNA [18]. The thermal cycling routine was $5 \mathrm{~min}$ at $95^{\circ} \mathrm{C}$ followed by 40 cycles at $95^{\circ} \mathrm{C}$ for $30 \mathrm{~s}, 60^{\circ} \mathrm{C}$ for $30 \mathrm{~s}$, and $72^{\circ} \mathrm{C}$ for $40 \mathrm{~s}$ in an ABI PRISM 7300 Detection System (Applied 
Liu et al.: DHEA Modulated Testosterone Biosynthesis

Table 1. Primer sequence of $\beta$-actin and targeted gene

\begin{tabular}{|c|c|c|c|c|}
\hline Gene & $\begin{array}{c}\text { Genbank acession } \\
\text { number }\end{array}$ & Primer sequences $\left(5^{\prime}-3^{\prime}\right)$ & Orientation & Product size (bp) \\
\hline$\beta$-actin & NM_031144 & $\begin{array}{l}\text { CCCTGTGCTGCTCACCGA } \\
\text { ACAGTGTGGGTGACCCCGTC }\end{array}$ & $\begin{array}{l}\text { Forward } \\
\text { Reverse }\end{array}$ & 186 \\
\hline $3 \beta-\mathrm{HSD}$ & NM_001007719 & $\begin{array}{l}\text { ACCCTTTAACTGCCACTTGGTC } \\
\text { AGTGTCCCGATCCACTCCGA }\end{array}$ & $\begin{array}{l}\text { Forward } \\
\text { Reverse }\end{array}$ & 141 \\
\hline $17 \beta$-HSD & NM_001004209 & $\begin{array}{l}\text { ATTGGAAGACTGACCGCCTACGAA } \\
\text { CGCCGCTGTTTCCTCGATGCC }\end{array}$ & $\begin{array}{l}\text { Forward } \\
\text { Reverse }\end{array}$ & 93 \\
\hline
\end{tabular}

Biosystems). According to the comparative threshold cycle (Ct) method, the amount of target mRNA normalized to $\beta$-actin relative to an internal control was calculated by $2^{-\Delta \Delta C t} ; \Delta \Delta \mathrm{Ct}=(\mathrm{Ct}$ ij-Ct $\beta$-actin j) (Ct i1-Ct $\beta$-actin1), where $\mathrm{Ct}$ ij and $\mathrm{Ct} \beta$-actin $\mathrm{j}$ are the $\mathrm{Ct}$ for gene i and $\beta$-actin in a sample j, respectively, and $\mathrm{Ct}$ i1 and Ct $\beta$-actin1 are the $\mathrm{Ct}$ in sample 1 expressed as the standard. The primers (Invitrogen, China) for $3 \beta$-HSD and $17 \beta-H S D$ are shown in Table 1.

\section{Western blot analysis}

The effects of DHEA on $3 \beta$-HSD, $17 \beta$-HSD, aromatase, CREB and p-CREB were measured by co-incubating the cells with 1,50 and $100 \mu \mathrm{M}$ concentrations of DHEA or vehicle for $24 \mathrm{~h}$ at $37^{\circ} \mathrm{C}$ and scraping for the subsequent determination of protein levels. Experiments were repeated three times, with six samples taken at each time point. Protein levels were measured using a bicinchoninic acid (BCA) protein determination kit. Extracted cells $(60 \mu \mathrm{g})$ were separated on a $10 \%$ SDS-polyacrylamide denaturing gel. Following SDSPAGE, proteins were electrophoretically transferred to Immobilone-P polyvinylidene difluoride membranes (Millipore, Billerica, MA, USA). The membranes were then blocked at $25^{\circ} \mathrm{C}$ for $2 \mathrm{~h}$ in blocking buffer [2-amino-2-hydroxymethyl-propane-1,3-diol (Tris)-buffered saline (TBS; pH7.6; Tris base 2.42g/l, NaCl $8 \mathrm{~g} / \mathrm{l}), 0.1 \%$ Tween- 20 , and $5 \%$ non-fat dry milk]. The proteins were incubated overnight at $4^{\circ} \mathrm{C}$ with rabbit anti-3 3 -HSD antibodies (1:1000 dilution; Abcam, USA), rabbit anti-17 $\beta$-HSD antibodies (1:1000 dilution; Santa Cruz, CA), rabbit anti-aromatase (1:1000 dilution; Abcam, USA), and rabbit anti-GAPDH (1:1000 dilution; CST, USA). After washing with TBS ( $\mathrm{pH} 8.0$ ) containing $0.1 \%$ Tween-20, goat anti-rabbit IgG with horseradish peroxidase conjugate (1:5000, Bioworld Technology Co., USA) in washing solution were added, and the solution was incubated for $1 \mathrm{~h}$ at room temperature. The immunoreactive proteins were detected by SuperSignal chemiluminescence. The protein bands were digitally imaged for densitometric quantification with a software program (Eastman Kodak Company, Rochester, NY, USA). Finally, the developed blots were subjected to densitometry using glyceraldehyde-3-phosphatedehydrogenase (GAPDH) as an internal control.

\section{ERK signaling analysis}

ERK1/2 and p-ERK1/2 protein levels. After culturing for $24 \mathrm{~h}$ in DMEM-F12 medium at $37^{\circ} \mathrm{C}$, cells were incubated with a dimethyl sulfoxide solution of DHEA $(1,50$ and $100 \mu \mathrm{M})$ for $30 \mathrm{~min}$. Control cultures received an equal volume of dimethyl sulfoxide, which did not exceed $0.25 \%(\mathrm{v} / \mathrm{v})$ in any experiment. Primary Leydig cells were pre-incubated with $10 \mu \mathrm{M}$ U0126 (inhibitor of p-ERK1/2) or vehicle for $60 \mathrm{~min}$, followed by the addition of $100 \mu \mathrm{M}$ DHEA for varying lengths of time in DMEM-F12 medium at $37^{\circ} \mathrm{C}$. After incubation, ERK1/2 and p-ERK1/2 protein levels in primary Leydig cells under basal or stimulated conditions were determined by Western blot as described above.

Testosterone content. Primary Leydig cells were pre-incubated with $10 \mu \mathrm{M}$ U0126 or vehicle for $60 \mathrm{~min}$, followed by the addition of 1,50 and $100 \mu \mathrm{M}$ DHEA for $24 \mathrm{~h}$ in DMEM-F12 medium at $37^{\circ} \mathrm{C}$. After incubation, the testosterone contents of primary Leydig cells were determined according to the manufacturer's instructions (intra-variation coefficients $<10 \%$, inter-variation coefficients $<15 \%$ ).

Assay of steroidogenic enzymes. Primary Leydig cells were pre-incubated with $10 \mu \mathrm{M}$ U0126 or vehicle for $60 \mathrm{~min}$, followed by the addition of $100 \mu \mathrm{M}$ DHEA for $24 \mathrm{~h}$ in DMEM-F12 medium at $37^{\circ} \mathrm{C}$. After incubation, the $3 \beta$-HSD, $17 \beta$-HSD and aromatase protein levels in primary Leydig cells under basal or stimulated conditions were determined by Western blot as described above. 
Statistical analysis

Data were analyzed with one-way ANOVA and expressed as mean values with standard errors. Treatment differences were subjected to a Duncan's multiple comparison tests. Differences were considered significant at $\mathrm{P}<0.05$. All statistical analyses were performed with SPSS 11.0 for Windows (StatSoft, Inc., Tulsa, OK, USA).

\section{Results}

Effect of DHEA on cell viability and testosterone content in primary Leydig cells

In the present study, we first determined the effect of DHEA on the cell viability of primary Leydig cells by MTT method. As shown in Fig. 1A, cells viability increased when primary Leydig cells were treated with $1-100 \mu \mathrm{M}$ DHEA for $24 \mathrm{~h}(P<0.01)$. Testosterone content was not detected in the control group, while a marked increase in testosterone was observed in the DHEA-treated groups $(P<0.01)$ in a dose-dependent manner (Fig. 1B).

\section{Effect of DHEA on $3 \beta$-HSD and $17 \beta$-HSD mRNA expression}

As shown in Fig. 2, the expression of $3 \beta-H S D$ mRNA was significantly higher in with 50 $\mu \mathrm{M}(P<0.05)$ and $100 \mu \mathrm{M}(P<0.01)$ treatment groups compared to the control group (Fig. $2 \mathrm{~A})$. The $100 \mu \mathrm{M}$ DHEA-treated cells also had significantly higher levels of $17 \beta$-HSD mRNA expression compared to control group $(P<0.05)$ (Fig. 2B). Thus, we used the $100 \mu \mathrm{M}$ DHEA treatment to culture primary Leydig cells to study its effect on the protein expression of steroidogenic metabolic enzyme.

\section{Effect of DHEA on steroidogenic metabolic enzyme protein levels}

To find out whether increased testosterone affected the protein levels of steroidogenic enzymes, the Leydig cellular steroidogenic enzymes protein expression levels were assayed. As shown in Fig. 3, with the extension of culture time, the protein levels of 3 $\beta$-HSD, 17 $\beta$-HSD and aromatase were not changed relative to the control group. The $3 \beta-\mathrm{HSD}$ and $17 \beta$-HSD protein levels showed an enhancement trend with treatment with DHEA; the $3 \beta$-HSD protein level was significantly increased from $12-48 \mathrm{~h}(P<0.05$; Fig. 3A), and the $17 \beta$-HSD protein level significantly increased from $24-48 \mathrm{~h}(P<0.05$; Fig. 3B). However, the aromatase protein level was significantly decreased at $48 \mathrm{~h}(P<0.05$; Fig. $3 \mathrm{C})$ with DHEA-treated primary Leydig cells.

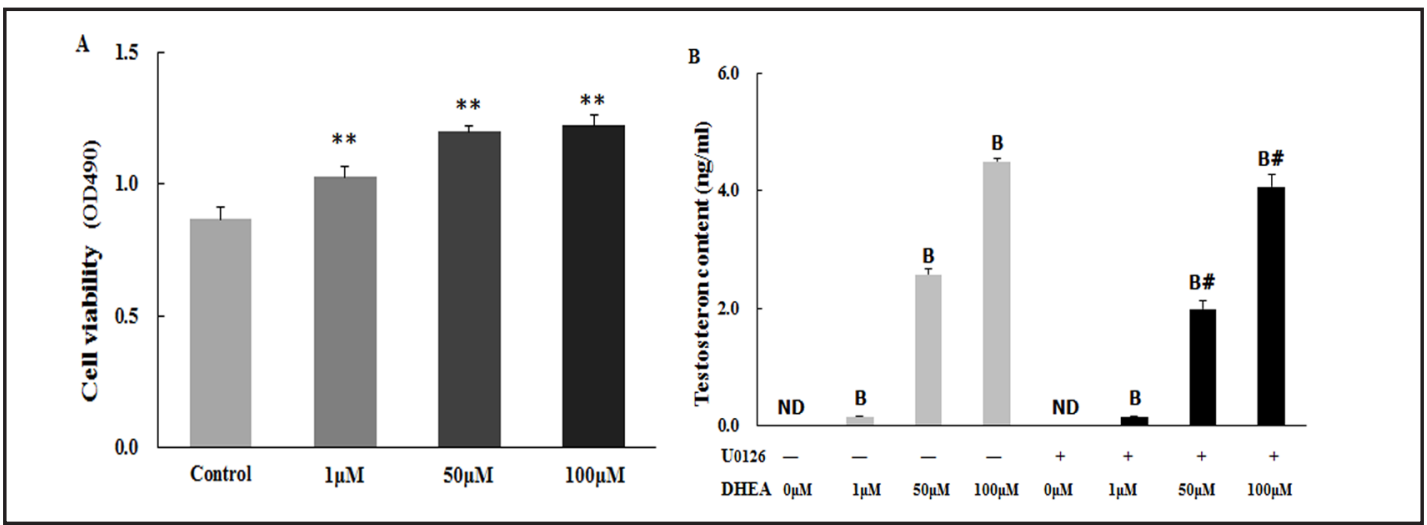

Fig. 1. Effect of DHEA on cell viability and testosterone content in primary Leydig cells. (A) Cells were treated with different dosage DHEA for24h, and then detected the cell viability by MTT methods. (B) Cells were pre-incubated with $10 \mu \mathrm{M}$ U0126 or vehicle for $60 \mathrm{~min}$ followed by the addition of 1, 50 or $100 \mu \mathrm{M}$ DHEA for 24h in DMEM-F12 medium. After incubation, testosterone content was detected using an RIA kit. Values are means $\pm S E(n=6)$. "ND" indicates testosterone concentrations below the detect limit. The significant difference between DHEA treatment group and respective control group was representing with capital letter "B". The difference between DHEA+U0126 and DHEA alone group was representing with "\#". 


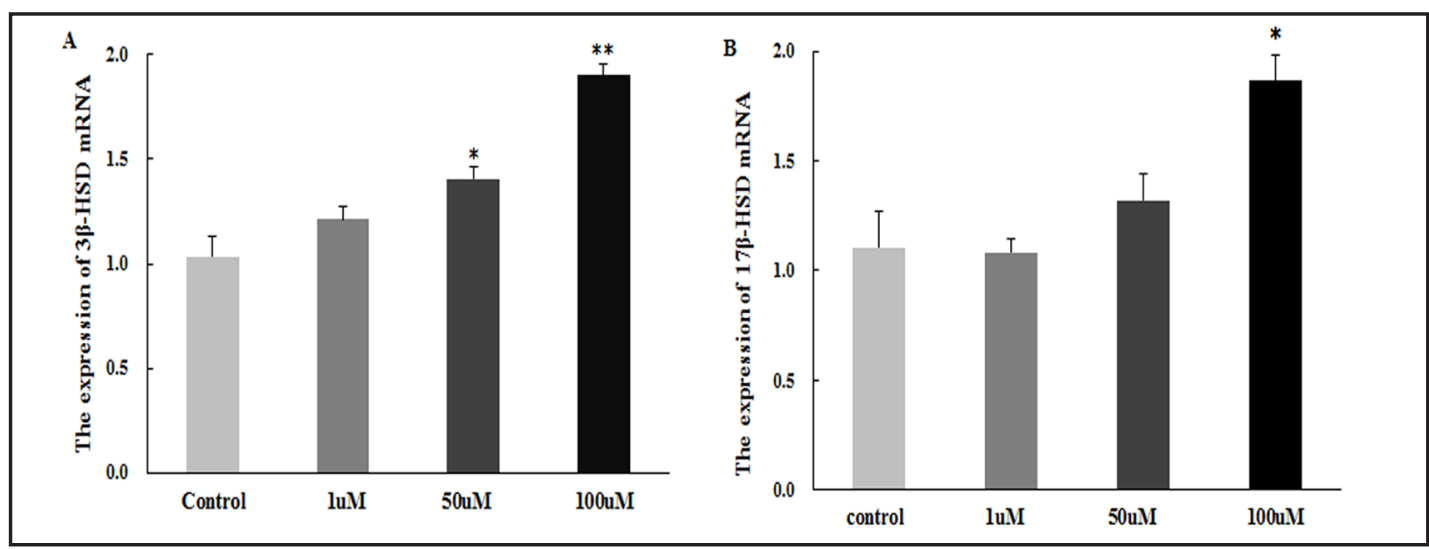

Fig. 2. Effect of DHEA on $3 \beta$-HSD and $17 \beta$-HSD mRNA expression in primary rat Leydig cells. (A) $3 \beta$-HSD and (B) $17 \beta$-HSD. Values are means \pm SE $(n=6)$. The mean values for DHEA-treated cells were significantly different from those of the control groups; ${ }^{*} P<0.05$, ${ }^{* *} P<0.01$.

Fig. 3. Effect of DHEA on the protein expression of steroidogenic metabolic enzymes. Results of statistical analysis for protein expression were normalized to GAPDH. (A) 3 $\beta$-HSD; (B) 17 $\beta$-HSD; and (c) aromatase. Values are means $\pm S E(n=6)$. Different letters indicate significant differences in DHEA-treated groups between different treatment times, $P<0.05$. * indicates the significant difference between DHEA-treated and control groups at the same time point, $P<0.05$.

Compared to the control group at the same time, $3 \beta$-HSD and $17 \beta$-HSD protein levels increased $(P<0.05$; Fig. $3 \mathrm{~A}$ and $\mathrm{B}$ ) while the level of aromatase protein decreased $(P<0.05$; Fig. 3C) when subjected to DHEA incubation for 24-48h in primary Leydig cells.

\section{ERK signaling analysis}

ERK1/2 and $p$-ERK1/2 protein levels. We first determined the effect of DHEA on ERK1/2 and p-ERK1/2 protein levels in primary Leydig cells. Compared to the control group, the results showed that DHEA treatment had no significant effect on total ERK1/2 protein levels, while p-ERK1/2 protein levels were significantly increased in 50 and 100 $\mu \mathrm{M}$ DHEA-treated groups $(P<0.05$; Fig. $4 A)$. Considering this result along with

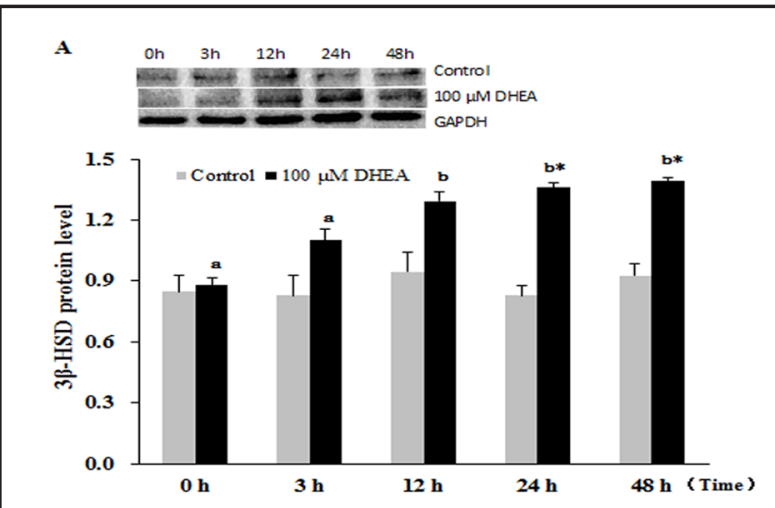

B
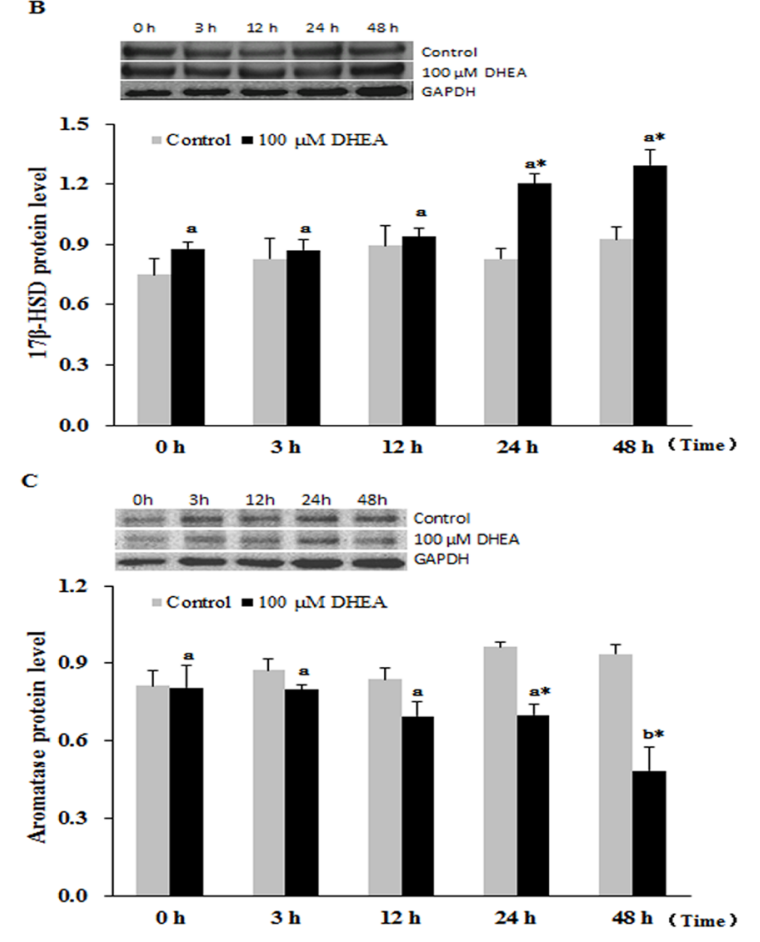


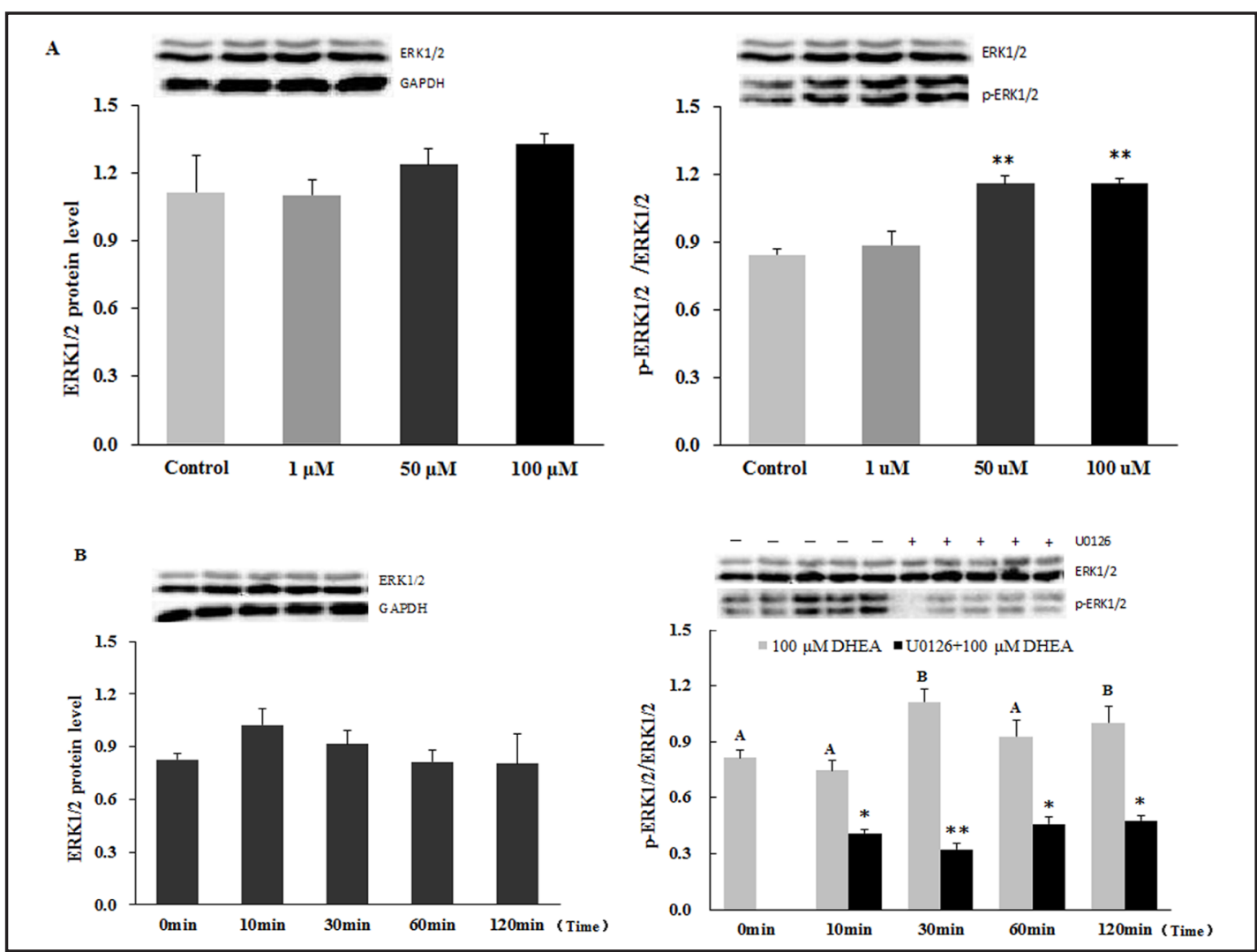

Fig. 4. Effect of DHEA on the protein expression of ERK1/2 and p-ERK1/2. (A) Primary Leydig cells were incubated in DMEM-F12 medium with various concentrations of DHEA $(1,50$ and $100 \mu \mathrm{M})$ or vehicle $(0 \mathrm{mM})$ for $30 \mathrm{~min}$. Values are means $\pm \mathrm{SE}(\mathrm{n}=6)$. The mean value was significantly different from that of the control group, ${ }^{*} P<0.05$, ${ }^{* *} P<0.01$. (B) Primary Leydig cells were pre-incubated with $10 \mu \mathrm{M}$ U0126 (inhibitor of p-ERK1/2) or vehicle for $60 \mathrm{~min}$, followed by the addition of $100 \mu \mathrm{M}$ DHEA for varying lengths of time in DMEM-F12 medium at $37^{\circ} \mathrm{C}$. Values are shown as means \pm SE $(n=6)$. The different capital letters indicate significant differences in the same treated group at different times $(P<0.01)$; the mean value of the treated group was significantly different than the control group at the same time, ${ }^{*} P<0.05$, ${ }^{* *} P<0.01$.

effect of DHEA on steroidogenic metabolic enzyme protein levels, we used the $100 \mu \mathrm{M}$ DHEA treatment to further study its effect on ERK1/2 and p-ERK1/2 protein levels.

Compared to the control, total protein ERK1/2 was unchanged with the extension of culture time, while levels of p-ERK1/2 were significantly higher at an experimental time of 30 and 120 min $(P<0.01$; Fig. 4B). We also found that the levels of p-ERK1/2 proteins were significantly lower during the experimental period from 10 to $120 \mathrm{~min}(P<0.05)$ compared to the control group, which was pre-incubated with U0126 (inhibitor of p-ERK1/2) and then treated by DHEA (Fig. 4B).

Testosterone contents. To determine whether DHEA elevates testosterone content by stimulating p-ERK1/2 protein expression, we examined testosterone content in primary Leydig cells pre-incubated with U0126 or vehicle. The results showed that testosterone contents were significantly increased by treatment with $1-100 \mu \mathrm{M}$ DHEA compared to controls groups either with or without U0126 incubation $(P<0.01$; Fig. 1B). However, the testosterone content was significantly decreased $(P<0.05)$ in the 50 or $100 \mu \mathrm{M}$ DHEA-treated groups with U0126 pre-incubation as compared to DHEA alone (Fig. 1B).

Steroidogenic enzymes protein levels. To investigate whether the change in testosterone content induced by the activation of $\mathrm{p}$-ERK1/2 by DHEA was due to alterations 3 $\beta$-HSD, $17 \beta$-HSD and aromatase protein levels, we performed a Western blot analysis. As shown KARGER 
Fig. 5. Effect of DHEA on p-ERK1/2-mediated steroidogenic enzymes protein levels. Primary Leydig cells were pre-incubated with $10 \mu \mathrm{M}$ U0126 (inhibitor of p-ERK1/2) or vehicle for $60 \mathrm{~min}$, followed by the addition of 100 $\mu \mathrm{M}$ DHEA for $24 \mathrm{~h}$ in DMEM-F12 medium at $37^{\circ} \mathrm{C}$. (A) $3 \beta$-HSD; (B) $17 \beta$-HSD; and $(\mathrm{C})$ aromatase. Protein levels were detected by Western blot analysis. Results are the mean of at least three separate Western blots. Values are means $(n=6)$ with standard errors represented by vertical bars. The different letters indicate significant differences when compared to the respective control group $(\mathrm{P}<0.05)$; the mean value was significantly different between groups with and without treatment with $\mathrm{U} 0126,{ }^{*} \mathrm{P}<0.05$.

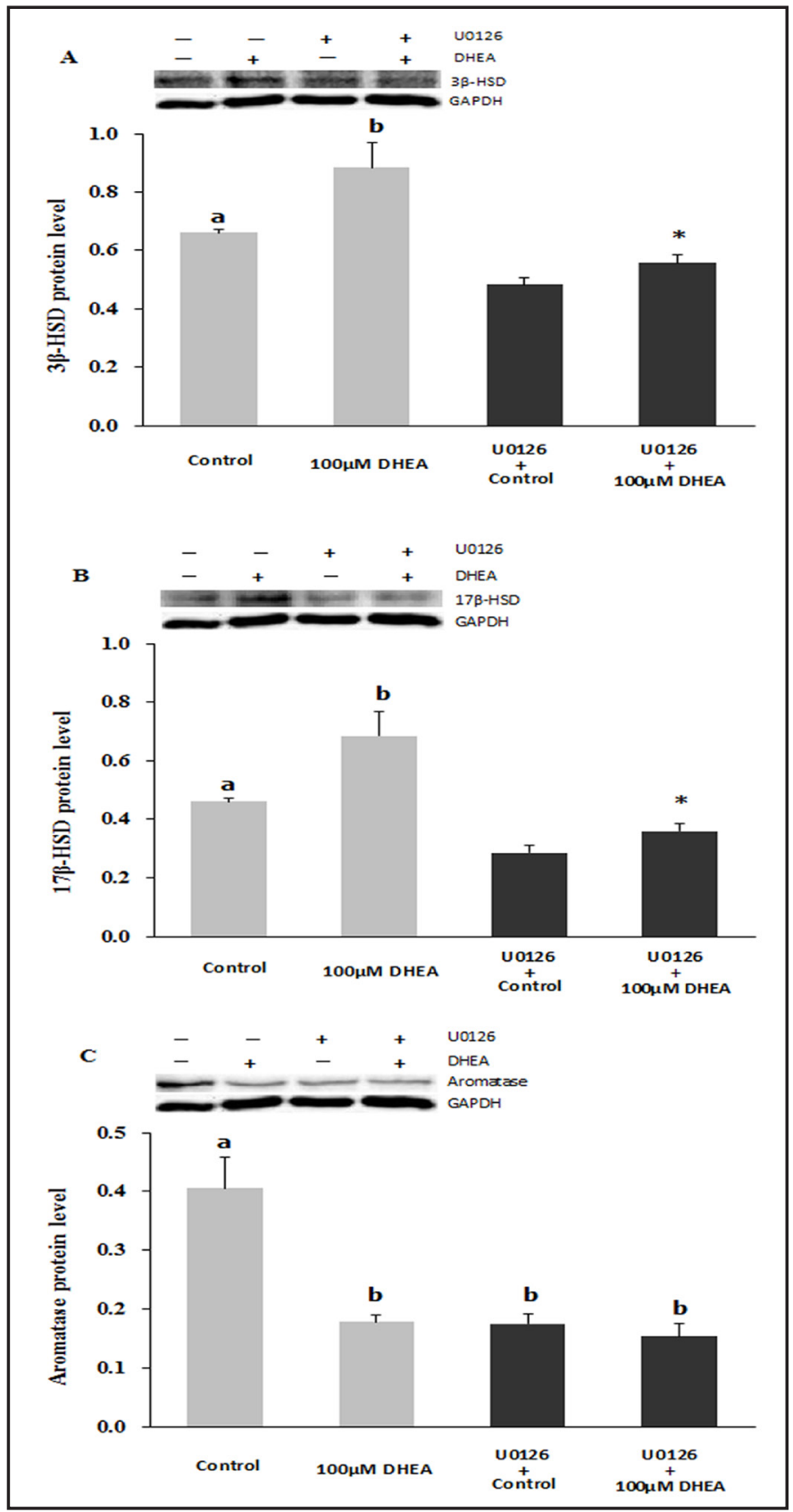

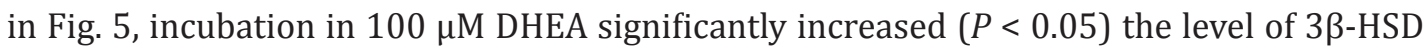
protein (Fig. $5 \mathrm{~A}$ ) and $17 \beta$-HSD protein (Fig. $5 \mathrm{~B}$ ), while the level of aromatase protein was decreased $(P<0.01)$ compared to the control group (Fig. 5C).

Compared to the control group, a marked decrease $(P<0.05)$ was observed in $3 \beta$-HSD (Fig. 5A) and 17 $\beta$-HSD (Fig. 5B) protein levels in cells pretreated with p-ERK1/2 inhibitors. Interestingly, no significant difference with the control was found in the level of aromatase protein in cells pretreated with p-ERK1/2 inhibitors (Fig. 5C).

Effect of DHEA on the expression of cAMP responsive element binding protein (CREB)

As shown in Fig. 6, no significant change in total CREB protein levels was observed with DHEA treatment, while p-CREB protein levels were significantly increased compared to the control in groups treated by 50 and $100 \mu \mathrm{M}$ DHEA $(P<0.05)$. 


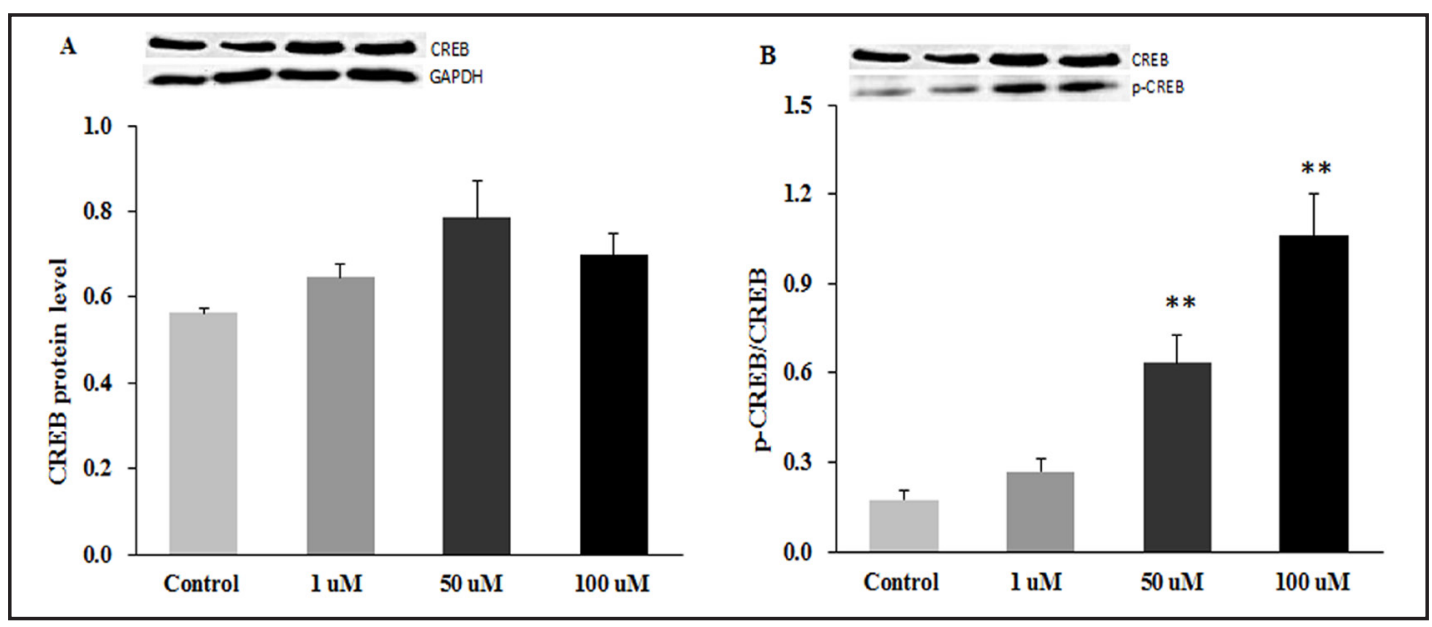

Fig. 6. Effect of DHEA on the CREB and p-CREB protein expression levels. (A) CREB and (B) p-CREB. Values are means $\pm S E(n=6)$. The mean value was significantly different from that of the control group, ${ }^{*} P<0.05$, $* * \mathrm{P}<0.01$.

\section{Discussion}

The major outcome of this study was demonstrating that DHEA targets the ERK1/2 signaling pathway in rat primary Leydig cells. DHEA directly enhanced the level of p-ERK1/2 and p-CREB proteins, which causes exogenous DHEA to preferentially convert to testosterone rather than estradiol. This preference is due to the up-regulation of $3 \beta-\mathrm{HSD}$ and 17 $\beta$-HSD protein levels along with the down-regulation of aromatase protein expression level in rat primary Leydig cells. Our findings demonstrate a novel signal pathway for DHEA action in primary Leydig cells, and provide a possible explanation for how DHEA carries out its biological functions.

Present results showed that cells viability was significant increase after $1-100 \mu \mathrm{M}$ DHEA treatment in primary Leydig cells, and this indicated that there no any cytotoxic effect of DHEA on Leydig cells. Also, a rapid increase in testosterone content was seen as the concentration increased from 1 to $100 \mu \mathrm{M}$, and maximum testosterone content accumulation was observed in the $100 \mu \mathrm{M}$ DHEA-treated group. These data are consistent with our previous study showing that DHEA can lead to high serum levels of testosterone in male rats [18] and higher concentrations of testosterone in TM-3 cells (a Leydig cell line) in a doseand time-dependent fashion [30]. Leblanc et al. [31] also reported that the administration of DHEA to cynomolgus monkeys significantly increased the serum concentrations of androstenedione and testosterone. DHEA can be converted into androstenedione by $3 \beta$-HSD in peripheral target tissues. It can then undergo further conversion to testosterone and estrone by $17 \beta-H S D$ and aromatase, respectively [10]. The expression of $3 \beta-H S D$ mRNA was significantly increased by treatment with 50 and $100 \mu \mathrm{M}$ DHEA. Cells treated with $100 \mu \mathrm{M}$ DHEA also had markedly higher $17 \beta-H S D$ mRNA expression when compared to the control group.

The adrenal cortex accounts for 75-90\% of the body's daily DHEA secretions; the remainder is produced by the testes and ovaries [32]. The sulfated form of DHEA (DHEAS) is a hydrophilic storage form that circulates in the blood, and DHEAS can be inter-converted with DHEA by DHEA sulfotransferases and hydroxysteroid sulfatases [13]. This conversion occurs in a wide range of tissues including the brain, liver, kidney, and gonads. DHEA is then metabolized to androstenedione, testosterone, estrogens, and other biologically active steroids, depending on the tissue. The present study showed that $3 \beta$-HSD and $17 \beta$-HSD protein levels in primary Leydig cells treated with $100 \mu \mathrm{M}$ DHEA were significantly increased at 24-48h, while the aromatase protein expression level were significantly decreased. This result was consistent with our previous study demonstrating the increase in $3 \beta-H S D$ 
and $17 \beta$-HSD protein levels following incubation with DHEA for 24 - $48 \mathrm{~h}$ along with the decrease in aromatase protein level in TM-3 cells [30]. These findings may be attributed to the increased delivery of intermediates, resulting in the variation of the protein level of the steroidogenic cascade because the precursor substrates also play an important role in enzyme biosynthesis [33].

Furthermore, the conversion of DHEA to other steroidal hormones depends upon the relative activity of key steroidogenic enzymes. Aromatase is a dual function enzyme that can catalyze the conversion of androstenedione to estrone and convert testosterone to estradiol [34]. It is generally acknowledged that the expression level of $3 \beta-H S D, 17 \beta-H S D$, aromatase and the hormone changes have potential correlation. Bourguiba et al. [35] demonstrated that androgens up-regulate the expression of aromatase in purified adult rat germ cells, whereas estrogens have the opposite effect. Li et al. [36] confirmed that the sex hormone precursor DHEA, which can be converted into estradiol by the enzyme aromatase, has a protective role against osteoarthritis. Our previous study showed that DHEA treatment significantly increased the content of estradiol in TM-3 cells, while the level of aromatase was decreased following treated with DHEA, and the results indicated that high estradiol concentrations result in down regulation of aromatase expression in TM-3 cells [30]. Given the present results and those from previous studies, although we did not detect estradiol content in the present study, we speculate that the down-regulation of aromatase protein level also may be due to the negative feedback of estradiol in primary Leydig cells. However, further study is needed to more precisely validate this hypothesis. DHEA is reported to be preferentially metabolized to androgens in women and estrogens in men [13,37]. Labrie [38]reported that DHEA supplementation in middle-aged or older men increases estradiol levels. Albrecht et al. [39] found that estradiol decreases DHEA secretion in pregnant baboons, indicating an estradiol-mediated negative feedback control of DHEA levels. However, in vitro studies using OBs demonstrated that DHEA can be metabolized to testosterone by $17 \beta$ - and $3 \beta$-HSD, and further metabolized to dihydrotestosterone by the 5a-reducatase types 1 and 2 enzymes [17]. In addition, Takeuchi et al. [11] showed that articular chondrocytes express steroidogenesisrelated enzyme genes such as $3 \beta-\mathrm{HSD}, 17 \beta$-HSD, and P450arom; the expression of these compounds did not change after the addition of DHEA, and sex steroid hormones were able to be locally synthesized from DHEA. Thus, we speculate that differences in the metabolism of exogenous DHEA depend on sex, age and target cells, and that the negative feedback effect of steroid concentrations in different tissues on key enzymes in the formation or metabolism of steroids should also be considered.

Our results suggest that exogenous DHEA could preferentially convert to testosterone rather than estradiol due to the un-regulation of $3 \beta-H S D$ and $17 \beta-H S D$ protein levels and the down-regulation of aromatase protein expression levels in primary Leydig cells. Several studies suggest that the MEK/ERK signaling pathway can play a critical role in steroidogenesis $[23,24]$. Nelson-Degrave et al. [24] demonstrated that the MEK/ERK pathway inhibits CYP17 gene expression in human Cal cells. Crosstalk between cAMP/PKA and MEK/ERK pathways has been previously described in the human adrenal NCI-H295R cell line [40]. DHEA may act directly by activating the MAPK signal transduction pathway [41]. Upon extracellular stimulation, the activated ERKs regulate additional signaling kinases that participate in the control steroidogenesis in granulosa-derived cell lines [22]. In the present study, DHEA generated no significant changes in the total ERK1/2 protein levels. Conversely, the p-ERK1/2 protein level was significantly increased by 50 and $100 \mu \mathrm{M}$ DHEA treatments. Several studies have shown that DHEA induces both genomic and non-genomic effects involving the ERK1/2 kinase pathway in the regulation of glucose uptake [42] and antiviral activity [42-44]. We also found that the levels of $\mathrm{p}$-ERK1/2 proteins were significantly lower when the primary Leydig cells pre-incubated with U0126 (inhibitor of p-ERK1/2); therefore, we speculate that DHEA, a steroid hormone, may affect the enhancement of $\mathrm{p}$-ERK1/2 protein levels in primary Leydig cells.

As shown in Fig.1, treatment with 50 or $100 \mu$ M DHEA combined with pre-incubation with U0126 resulted in a significant decrease in testosterone content. Western blot results 
showed that pre-incubation with U0126 could reverse the increased levels of 3 $\beta$-HSD and $17 \beta$-HSD proteins generated by DHEA in primary Leydig cells, while the aromatase protein level was unaffected. DHEA has been identified as a potent agonist for the sigma $1(\sigma 1)$ receptor [45]. Activation of this receptor also enhances the NGF-induced neurite outgrowth by modulating the MEK-ERK and PI3K-Akt-mTOR signaling pathways [46]. However, recent findings indicate that genomic effects of DHEA in PC12 cells are membrane-mediated and involve PKA and MAPK pathways but not a nuclear receptor [25]. These results reinforce the idea that DHEA can activate p-ERK1/2, thus enhancing the expression of $3 \beta$-HSD and $17 \beta$-HSD and improving testosterone biosynthesis in primary Leydig cells.

Previous study have observed that DHEA induce the proliferation of estrogen and androgen receptor positive breast cancer cells, but inhibit the proliferation in estrogen receptor negative cells [47]. Also, Nephew et al. [48] reported that DHEA inhibits estradiol binding to its receptor in vivo in yeast. Although DHEA and its downstream conversion product androstenedione are often referred to as adrenal androgens, they actually do not represent androgens since they do not bind with high affinity to classical intracellular the androgen receptor [49]. To date, no nuclear steroid receptor with high affinity for DHEA has been found [49] and the mechanisms by which DHEA operated are not fully understood. Transcription factor network analysis identified CREB as the master regulator in the control of gene expression in steroid-related pathways [50]. Many steroidogenic gene promoters exhibit cAMP response elements (CREs) or CRE-like sequences, highlighting the major role of the cAMP pathway in regulating steroid hormone biosynthesis [51]. In this study, DHEA treatment caused a significant up-regulation of the p-CREB protein level in cultured rat primary Leydig cells. This result was consistent with Moriguchi et al. [27], who reported that DHEA significantly restored the reduced ERK phosphorylation concomitant with increased CREB phosphorylation in hippocampal ca1. Saxena et al. [52] reported that DHEA regulates the MAPK pathway in humans via a novel MAPK phosphatase, which not only controls the activity of MAPKs, but also mediates crosstalk between the cAMP system and the MAPK cascade. However, Ren at al. [53] reported that chronic treatment with DHEA did not affect the cAMP level up-regulated by withdrawal, suggesting the role of a non-cAMP/PKA pathway in the regulation of MAPK activation. Combined with these previous studies, the present results lead us to speculate that DHEA can act via an ERK cascade to up-regulate p-CREB, directly enhancing the $3 \beta$-HSD and $17 \beta$-HSD protein levels. This results in the improvement of testosterone biosynthesis in primary Leydig cells in vitro. Further study, however, is needed to more precisely validate this hypothesis.

In summary, using an in vitro model to study the effect of DHEA on testosterone biosynthesis in male animals, we found that DHEA could preferentially convert to testosterone rather than estradiol due to the up-regulation of 3 $\beta$-HSD and $17 \beta$-HSD proteins and the down-regulation of aromatase protein in primary Leydig cells. This DHEA effect, at least in part, was associated with the elevation of p-ERK1/2 and p-CREB protein levels. On the basis of these results, we speculate that DHEA is a clinical agent for the alleviation of aging-associated pathophysiological conditions in humans; however, this supposition requires further investigation.

\section{Disclosure Statement}

All of author has none declared.

\section{Acknowledgments}

This work was supported by the Program for New Century Excellent Talents in University (No.NCET-10-0495) and A Project Funded by the Priority Academic Program Development 


\section{Cellular Physiology Cell Physiol Biochem 2015;36:1778-1792

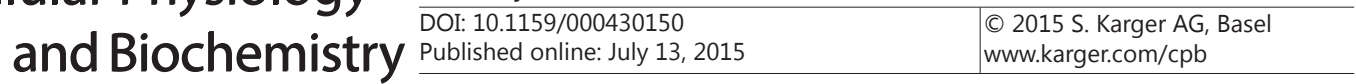

Liu et al.: DHEA Modulated Testosterone Biosynthesis

of Jiangsu Higher Education Institutions (PAPD). We are also grateful to Dr. William W. Riley for his critical reading of the manuscript.

\section{References}

1 Feldman HA, Johannes CB, Araujo AB, Mohr BA, Longcope C, McKinlay JB: Low dehydroepiandrosterone and ischemic heart disease in middle-aged men: Prospective results from the massachusetts male aging study. Am J Epidemiol 2001;153:79-89.

2 Genazzani AD, Lanzoni C, Genazzani AR: Might DHEA be considered a beneficial replacement therapy in the elderly? Drug Aging 2007;24:173-185.

-3 Baulieu EE, Thomas G, Legrain S, Lahlou N, Roger M, Debuire B, Faucounau V, Girard L, Hervy MP, Latour F, Leaud MC, Mokrane A, Pitti-Ferrandi H, Trivalle C, de Lacharriere O, Nouveau S, Rakoto-Arison B, Souberbielle JC, Raison J, Le Bouc Y, Raynaud A, Girerd X, Forette F: Dehydroepiandrosterone (DHEA), DHEA sulfate, and aging: Contribution of the DHEAge study to a sociobiomedical issue. P Natl Acad Sci USA 2000;97:4279-4284.

4 Labrie F, Luu-The V, Labrie C, Belanger A, Simard J, Lin SX, Pelletier G: Endocrine and intracrine sources of androgens in women: Inhibition of breast cancer and other roles of androgens and their precursor dehydroepiandrosterone. Endocr Rev 2003;24:152-182.

5 Bacsi K, Kosa J, Lazary A, Horvath H, Balla B, Lakatos P, Speer G: Significance of dehydroepiandrosterone and dehydroepiandrosterone sulfate in different diseases. Orvosi Hetilap 2007;148:651-657.

6 Legrain S, Girard L: Pharmacology and therapeutic effects of dehydroepiandrosterone in older subjects. Drug Aging 2003;20:949-967.

7 Sorwell KG, Urbanski HF: Dehydroepiandrosterone and age-related cognitive decline. Age 2010;32:61-67.

8 Wolf OT, Kirschbaum C: Actions of dehydroepiandrosterone and its sulfate in the central nervous system: Effects on cognition and emotion in animals and humans. Brain Res Rev 1999;30:264-288.

19 Chang L-L, Wun W-SA, Wang PS: Mechanisms of inhibition of dehydroepiandrosterone upon corticosterone release from rat zona fasciculata-reticularis cells. J Cell Biochem 2008;104:359-368.

10 Labrie F, Luu-The V, Labrie C, Simard J: DHEA and its transformation into androgens and estrogens in peripheral target tissues: Intracrinology. Front Neuroendocrin 2001;22:185-212.

11 Takeuchi S, Mukai N, Tateishi T, Miyakawa S: Production of sex steroid hormones from DHEA in articular chondrocyte. Am J Physiol-Endoc M 2007;293:E410-E415.

12 Schwartz AG, Pashko LL: Dehydroepiandrosterone, glucose-6-phosphate dehydrogenase, and longevity. Ageing Res Rev 2004;3:171-187.

13 Arlt W, Haas J, Callies F, Reincke M, Hubler D, Oettel M, Ernst M, Schulte HM, Allolio B: Biotransformation of oral dehydroepiandrosterone in elderly men: Significant increase in circulating estrogens. J Clin Endocr Metab 1999;84:2170-2176.

14 Arlt W, Justl HG, Callies F, Reincke M, Hubler D, Oettel M, Ernst M, Schulte HM, Allolio B: Oral dehydroepiandrosterone for adrenal androgen replacement: Pharmacokinetics and peripheral conversion to androgens and estrogens in young healthy females after dexamethasone suppression. J Clin Endocr Metab 1998;83:1928-1934.

15 Labrie F, Belanger A, Belanger P, Berube R, Martel C, Cusan L, Gomez J, Candas B, Chaussade V, Castiel I, Deloche C, Leclaire J: Metabolism of dhea in postmenopausal women following percutaneous administration. J Steroid Biochem 2007;103:178-188.

16 Morales AJ, Haubrich RH, Hwang JY, Asakura H, Yen SSC: The effect of six months treatment with a $100 \mathrm{mg}$ daily dose of dehydroepiandrosterone (DHEA) on circulating sex steroids, body composition and muscle strength in age-advanced men and women. Clin Endocrinol 1998;49:421-432.

17 Wang L, Wang YD, Wang WJ, Li DJ: Differential regulation of dehydroepiandrosterone and estrogen on bone and uterus in ovariectomized mice. Osteoporosis Int 2009;20:79-92.

18 Song L, Tang X, Kong Y, Ma H, Zou S: The expression of serum steroid sex hormones and steroidogenic enzymes following intraperitoneal administration of dehydroepiandrosterone (DHEA) in male rats. Steroids 2010;75:213-218. 


\section{Cellular Physiology Cell Physiol Biochem 2015;36:1778-1792

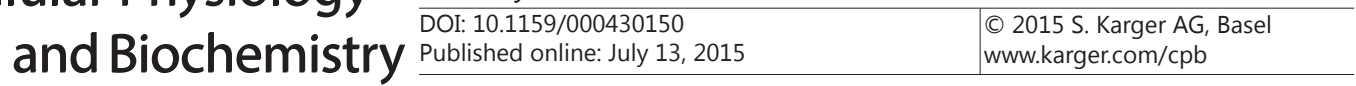

19 Shen X, Liu L, Yin F, Ma H, Zou S: Effect of dehydroepiandrosterone on cell growth and mitochondrial function in tm-3 cells. Gen Comp Endocr 2012;177:177-186.

20 Kumar V, Balomajumder C, Roy P: Disruption of LH-induced testosterone biosynthesis in testicular leydig cells by triclosan: Probable mechanism of action. Toxicology 2008;250:124-131.

-21 Hanukoglu I: Steroidogenic enzymes - structure, function, and role in regulation of steroid-hormone biosynthesis. J Steroid Biochem 1992;43:779-804.

22 Seger R, Hanoch T, Rosenberg R, Dantes A, Merz WE, Strauss JF, Amsterdam A: The erk signaling cascade inhibits gonadotropin-stimulated steroidogenesis. J Biol Chem 2001;276:13957-13964.

-23 Tajima K, Dantes A, Yao Z, Sorokina K, Kotsuji F, Seger R, Amsterdam A: Down-regulation of steroidogenic response to gonadotropins in human and rat preovulatory granulosa cells involves mitogen-activated protein kinase activation and modulation of dax-1 and steroidogenic factor-1. J Clin Endocr Metab 2003;88:2288-2299.

-24 Nelson-Degrave VL, Wickenheisser JK, Hendricks KL, Asano T, Fujishiro M, Legro RS, Kimball SR, Strauss JF, McAllister JM: Alterations in mitogen-activated protein kinase kinase and extracellular regulated kinase signaling in theca cells contribute to excessive androgen production in polycystic ovary syndrome. Mol Endocrinol 2005;19:379-390.

25 Charalampopoulos I, Margioris AN, Gravanis A: Neurosteroid dehydroepiandrosterone exerts antiapoptotic effects by membrane-mediated, integrated genomic and non-genomic pro-survival signaling pathways. J Neurochem 2008;107:1457-1469.

26 Chang LL, Wun WSA, Ho LLT, Wang PS: Effects of dehydroepiandrosterone on corticosterone release in rat zona fasciculata-reticularis cells. N-S Arch Pharmacol 2003;368:487-495.

27 Moriguchi S, Yamamoto Y, Ikuno T, Fukunaga K: Sigma-1 receptor stimulation by dehydroepiandrosterone ameliorates cognitive impairment through activation of CaM kinase $I$, protein kinase $\mathrm{c}$ and extracellular signal-regulated kinase in olfactory bulbectomized mice. J Neurochem 2011;117:879-891.

28 Murugesan P, Muthusamy T, Balasubramanian K, Arunakaran J: Polychlorinated biphenyl (aroclor 1254) inhibits testosterone biosynthesis and antioxidant enzymes in cultured rat leydig cells. Reprod Toxicol 2008;25:447-454.

29 Aldred LF, Cooke BA: The effect of cell damage on the density and steroidogenic capacity of rat testis leydig cells, using an nadh exclusion test for determination of viability. J Steroid Biochem 1983;18:411-414.

30 Xuehuai Shen, Jian Kang, Jing Han, Guanxing Liu, Haitian Ma, Sixiang Zou: Influence the content of steroid hormones and expression of steroidogenic enzymes with DHEA-treated in tm-3 cells. J Anim Vet Adv 2013;12:831-838.

31 Leblanc M, Labrie C, Belanger A, Candas B, Labrie F: Pharmacokinetics of oral dehydroepiandrosterone (DHEA) in the ovariectomised cynomolgus monkey. J Steroid Biochem 2002;81:159-164.

-32 Savineau J-P, Marthan R, de la Roque ED: Role of DHEA in cardiovascular diseases. Biochem Pharmacol 2013;85:718-726.

33 Sanderson T, van den Berg M: Interactions of xenobiotics with the steroid hormone biosynthesis pathway. Pure Appl Chem 2003;75:1957-1971.

-34 Payne AH, Hales DB: Overview of steroidogenic enzymes in the pathway from cholesterol to active steroid hormones. Endocr Rev 2004;25:947-970.

-35 Bourguiba S, Lambard S, Carreau S: Steroids control the aromatase gene expression in purified germ cells from the adult male rat. J Mol Endocrinol 2003;31:83-94.

-36 Li W, Tang L, Xiong Y, Zhou X, Wu L: The chondroprotective effects of dehydroepiandrosterone probably exerted by its conversion to estradiol. J Steroid Biochem 2013;134:15-22.

37 Frye RF, Kroboth PD, Kroboth FJ, Stone RA, Folan M, Salek FS, Pollock BG, Linares AM, Hakala C: Sex differences in the pharmacokinetics of dehydroepiandrosterone (DHEA) after single- and multiple-dose administration in healthy older adults. J Clin Pharmacol 2000;40:596-605.

38 Labrie F: DHEA, important source of sex steroids in men and even more in women. Prog Brain Res 2010;182:97-148.

-39 Albrecht ED, Aberdeen GW, Pepe GJ: Estrogen elicits cortical zone-specific effects on development of the primate fetal adrenal gland. Endocrinology 2005;146:1737-1744.

40 Sewer MB, Waterman MR: cAMP-dependent protein kinase enhances cyp17 transcription via MKP-1 activation in h295r human adrenocortical cells. J Biol Chem 2003;278:8106-8111. 


\section{Cellular Physiology Cell Physiol Biochem 2015;36:1778-1792 \begin{tabular}{l|l} 
and Biochemistry 10.1159/000430150 & $\begin{array}{l}\text { Doblisned onine: July 15, 2015 } \\
\text { Pul S. Karger AG, Basel } \\
\text { www.karger.com/cpb }\end{array}$ \\
\cline { 2 - 3 }
\end{tabular}}

Liu et al.: DHEA Modulated Testosterone Biosynthesis

41 Williams MRI, Ling SH, Dawood T, Hashimura K, Dai AZ, Li H, Liu JP, Funder JW, Sudhir K, Komesaroff PA: Dehydroepiandrosterone inhibits human vascular smooth muscle cell proliferation independent of ARs and ERs. J Clin Endocr Metab 2002;87:176-181.

42 Liu D, Iruthayanathan M, Homan LL, Wang Y, Yang L, Wang Y, Dillon JS: Dehydroepiandrosterone stimulates endothelial proliferation and angiogenesis through extracellular signal-regulated kinase 1/2-mediated mechanisms. Endocrinology 2008;149:889-898.

43 Formoso G, Chen H, Kim JA, Montagnani M, Consoli A, Quon MJ: Dehydroepiandrosterone mimics acute actions of insulin to stimulate production of both nitric oxide and endothelin 1 via distinct phosphatidylinositol 3-kinase- and mitogen-activated protein kinase-dependent pathways in vascular endothelium. Mol Endocrinol 2006;20:1153-1163.

44 Torres NI, Castilla V, Bruttomesso AC, Eiras J, Galagovsky LR, Wachsman MB: In vitro antiviral activity of dehydroepiandrosterone, 17 synthetic analogs and erk modulators against herpes simplex virus type 1. Antivir Res 2012;95:37-48.

45 Hashimoto K: Sigma-1 receptor chaperone and brain-derived neurotrophic factor: Emerging links between cardiovascular disease and depression. Prog Neurobiol 2013;100:15-29.

46 Nishimura T, Ishima T, Iyo M, Hashimoto K: Potentiation of nerve growth factor-induced neurite outgrowth by fluvoxamine: Role of sigma-1 receptors, IP3 receptors and cellular signaling pathways. Plos One 2008;3: DOI: 10.1371/journal.pone.0002558

47 Toth-Fejel SE, Cheek J, Calhoun K, Muller P, Pommier RF: Estrogen and androgen receptors as comediators of breast cancer cell proliferation. Arch Surg 2004;139:50-54.

48 Nephew KP, Sheeler CQ, Dudley MD, Gordon S, Nayfield SG, Khan SA: Studies of dehydroepiandrosterone (DHEA) with the human estrogen receptor in yeast. Mol Cell Endocrinol 1998;143:133-142.

-49 Widstrom RL, Dillon JS: Is there a receptor for dehydroepiandrosterone or dehydroepiandrosterone sulfate? Semin in Reprod Med 2004;22:289-298.

50 Vanparys C, Hectors TLM, Blust R, De Coen W: Mechanistic profiling of the cAMP-dependent steroidogenic pathway in the h295r endocrine disrupter screening system: New endpoints for toxicity testing. Toxicol Lett 2012;208:174-184.

51 Manna PR, Wang XJ, Stocco DM: Involvement of multiple transcription factors in the regulation of steroidogenic acute regulatory protein gene expression. Steroids 2003;68:1125-1134.

52 Saxena M, Williams S, Tasken K, Mustelin T: Crosstalk between cAMP-dependent kinase and MAP kinase through a protein tyrosine phosphatase. Nat Cell Biol 1999;1:305-311.

-53 Ren X, Noda Y, Mamiya T, Nagai T, Nabeshima T: A neuroactive steroid, dehydroepiandrosterone sulfate, prevents the development of morphine dependence and tolerance via c-fos expression linked to the extracellular signal-regulated protein kinase. Behav Brain Res 2004;152:243-250. 